\title{
木製トラス橋の製作と歩行実験による 体験型学習の取り組み
}

\author{
Efforts of Hands-on Experimental Learning through Construction and \\ Walking Experiment of Wooden Truss Bridges
}

\author{
東 山 浩 $士^{* 1}$ \\ Hiroshi HIGASHIYAMA \\ 嶋 津 治 希※1 \\ Haruki SHIMAZU \\ 桝下 文 夫※1 \\ Fumio YAGISHITA
}

\begin{abstract}
It is necessary to train not only lectures and exercises but also design and team work skills through hands-on experimental learning. In our department, as the efforts of hands-on experimental learning, construction and walking experiment of wooden truss bridges with about $2 \mathrm{~m}$ span length, which are constructed with adhesive only, are conducted. The aims of this subject are the cultivation of team work skills and the leadership in the engineering education. It is also intended to look back the degree of understanding and the significance of learning of "Structural Mechanics" as one of the fundamental subjects in the civil engineering. In this paper, we introduce the efforts of hands-on experimental learning and educational effects through the construction and walking experiment of wooden truss bridges and questionnaire results.

Keywords: Engineering Education, Hands-on Experimental Learning, Wooden Truss Bridges, Team Work Skills, Structural Mechanics

キーワード：工学教育, 体験型学習, 木製トラス橋, チームワーク力, 構造力学
\end{abstract}

\section{1.はじめに}

著者らが所属する学科は，2003年度に日本技術者教育 認定機構（JABEE）の「土木及び土木関連分野」で審査 を受けた。当時のJABEE基準であった「種々の科学技術 および情報を利用して社会の要求を解決するためのデザ イン能力」,「与えられた制約条件の下で計画的に仕事を 進め, まとめる能力」に対応するため, 講義や演習など の座学だけでなく, 体験型学習によるデザイン力, チー ムワーク力の養成が必要であった ${ }^{1)}$ 。そこで， 2 年間の 準備期間を設け，2003年度から 1 年生を対象とした「実 験道場」（第 2 セメスター, 選択必修）を新規開講した。

この「実験道場」は, カンタベリー大学（ニュージー ランド）にて実施されているStudent Bridge Building Competition $^{1)}$ を参考に, 在外研究のためにカンタベリ 一大学に 1 年間滞在した経験を有する第 3 著者が主導し て立ち上げた科目である。本科目は，支間長約 $2 \mathrm{~m}$ の木 製トラス橋を接着椷（木工用）のみで製作し，トラス橋 上を歩行する実験を通しての体験型学習である。また, 1 年生の前期に学習した土木系学科の基礎科目である 「構造力学 I」の影響線を援用することから, その理解 度の向上や学習への動機づけをも意図している。ケラー

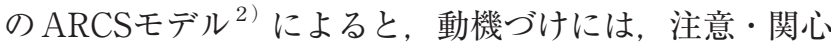
(Attention), 関連性 (Relevance), 自信 (Confidence), 満足感 (Satisfaction) を与えることが重要であると言わ

2018 年 3 月 15 日受付

※ 1 近畿大学理工学部
れている．本科目では，これら4つの観点を踏まえた内 容設計に基づいている。本科目における教育の実践, 指 導方針の検証については立ち上げ後の 2 年間の取り組み についてすでに発表している3 ${ }^{3), 4) . ~}$

本科目の開講から現在まで約 15 年が経過したが, その 間のCAP制導入に伴う時間数の削減, カリキュラムの見 直しなどが余儀なくされた。 これにより本科目の内容も 一部変更することになり，2013年度から科目名を「基礎 ゼミ2」(第 2 セメスター, 必修) に変更したが, 学習教 育目的・目標は変更することなく, 本学科の特色ある科 目としての位置付けは現在も継続されている. 本科目の 学習教育目的・目標は, 「木製トラス橋の製作および歩行 実験を通して, 『自発的に学ぶこと』, 『探求する姿勢をも つこと』を実践し，『物事を進める手順や考え方』，『グ ループ活動の意義とリーダーシップの必要性』を体感す る.」である.

本稿では, 本学科における体験型学習の取り組み内容 とアンケート結果から見られる教育効果について事例紹 介する。

\section{2. 体験型学習（基礎ゼミ2）の取り組み 2. 1 内容設計}

先に挙げたケラーの ARCSモデル ${ }^{2)}$ の 4 つの観点と本 科目の内容設計との関連について述べる.

学生に「注意・関心」を抱かせるためには対象とする 課題の規模や重要度, さらに学習した授業内容の活用が 重要であると言える。本科目は 1 年生の後期に開講する 
ことを踏まえ，構造力学を援用した木製トラス橋を題材 として取り上げることにした。また，そのトラス橋上を 歩行した実験であることが関心を抱かせる大きな要因に なり得ると考えた，近年では，2007年に米国ミネソタ州 で落橋したミシシッピ川橋5)を導入講義で紹介すること によってさらなる「注意・関心」を喚起させている.

1 年生の前期に学習した構造力学 I の内容（影響線） が実際の構造物の設計とどのように関わっているのか, さらにチームのなかで積極的に取り組むことによる課題 との「関連性」について導入講義で認識させる必要があ ると考えた。

「自信」は「達成感」と置き換えてもよいのかもしれな いが，各回の最初に当日の目標を示し，限られた時間内 で作業を完結できるように構成する必要があった．本科 目の立ち上げ当初は教員も手探りの状態であったが，作 業効率と製作精度の確保について継続的に工夫を重ねて きた。また，歩行実験の成功が学生個々の自信とその後 のチームワークカやリーダーシップを育むことになり， さらには「満足感」を得ることができる。 そのために後 述する 1 人歩行実験の成功率をある程度確保するための 改善を図ってきた，一方，失敗に終わったチームへのフ オローとしては, 最終回に扔ける総括・講評において失 敗原因や反省点を教員が説明することにした。

\section{2 基本方針}

本科目の目的・目標は, 学生のリーダーシップ, チー ムワーク力の醇成であるので, 各回の初めに作業内容お よび注意事項を説明し，必要な資料の配布を行うのみと し，学生から自発的に質問があった際にのみ教員が対応 することを基本方針としている．しかし，指示内容と明 らかに異なる作業をしている場合には，その誤りを直接 指摘することは避け，学生にはどこが間違っているのか を配布資料から気付かせるように努めることにした．ま た，一連の作業では，鋸やボール盤などの木材を加工す る工具や機器材を使用するので，思わ怪我をしないよ うにその取り扱いについては見回りながら注意喚起する こともある．学生の中には，これまでに工作や工具の取 り扱いの経験に乏しい者も㧍り，近年ではそれが増加傾 向にあるように感じられる，充分な説明だけでなく，予 め教員が実際にやって見せることが危険回避として重要 である。

\section{3 取り組みの内容}

本科目は 1 年生の後期に開講しており, 必修科目であ るため, 現在は定員 100 名に対して, 1 班 $7 \sim 8$ 名の構成

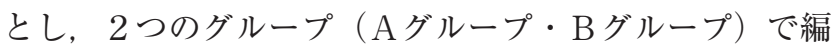
成することにより, 所定の単位数に応じた時間数を確保 している. 本科目の実施計画表を表 1 に示す.初回の導入 講義では, 本科目の位置付け, 学習教育目的・目標, 構 造力学科目との関連性, ミシシッピ川橋の落橋事故, 受 講に対する心構えについて説明した後, 過去の成功例・ 失敗例を紹介している。受講に対する心構え（実験を成 功に導くために！）は以下の 6 項目を説明している.

（1）各自がリーダーシップを心掛ける.

（2）事前説明を真摰に聞き，他人任せにしない.
表 1 基礎ゼミ 2 の実施計画表

\begin{tabular}{|c|c|}
\hline 実施回 & 実 施 内 \\
\hline (1) & 導入講義, トラス橋の影響線の計算 \\
\hline (2) & 影響線の確認，引張試験片の作製 \\
\hline (3) & $\begin{array}{l}\text { 引張試験, 接着面積の算出, ガセットの穴開けお } \\
\text { よび組み立て線の記入 }\end{array}$ \\
\hline (4) & $\begin{array}{l}\text { トラス弦材の切り出し, テーピング, 接着面積の } \\
\text { 切り抜き }\end{array}$ \\
\hline (5) & トラス橋の組み立て \\
\hline (6) & 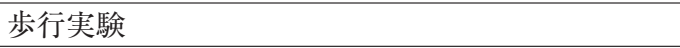 \\
\hline (7) & A・Bグループ合同による総括・講評 \\
\hline
\end{tabular}

（3）自分の作業に責任を持つ.

（4）作業に対しては絶えず“正確”を心掛ける。

（5）作業の各段階での相互チェックを必ず行う.

（6）遅刻・欠席をしない.

トラス橋の歩行実験では, 「1 人歩行においてトラス橋 は崩壊しない. 」, 「2 人歩行に拈いて部材力が最大となる 位置まで移動した時にトラス橋は崩壊する.」という $2 つ$ の条件を設定している. トラス橋の形式は, 予め教員が 設定した図 1 に示す 7 種類である. 各班のリーダーによ る抽選で取り組むトラス橋を決め, トラス橋の寸法につ いての情報（図面）を与える. 1 年生の前期に学習した 「構造力学 I」を援用してトラス橋の影響線を各班で協働 して計算させている。影響線の計算は第 3 回までに合格 しなければその先の工程へ進めないことを説明し，期限 を守らせている。第 2 回目は, 接着剂（木工用）の接着 強度を求めるための引張試験片を作製する。 トラス橋は 接着剂のみで組み立てるため, 引張試験は接着強度のキ ヤリブレーションを行うのが目的である。なお，木材は 厚さ $12 \mathrm{~mm}$ の合板を使用している. 図 2 に示す 3 種類の 接着面積を有する引張試験片を作製し， 1 週間の養生期 間を設けた後, 第 3 回目に引張試験を行い（図 3 ), 接着 強度と接着面積の関係を求める。 この結果と歩行実験に 参加するメンバーの体重および先に計算した影響線を基 に, 各班で必要とする接着面積を算出させる. 接着面積 の算出過程については，そのチェックを兼ねて各班のリ ーダーに口頭での説明を求めている。 また，これと並行 してトラス橋のガセット部の穴開け掞よび組み立て線の 記入を行う。第 4 回目にはトラス橋の弦材を所定の寸法 に切り出し (図 4 ), 接着部のテーピングおよび接着面積 を確保するためのテーピング箇所の切り抜きを行う。第 5 回目はトラス橋の組み立て（図 5 ) を行い, 引張試験 片と同様の条件とするために 1 週間の養生期間を設けた 後, 歩行実験を行う (図 6 ). 最終回には, 担当教員によ る引張試験結果および歩行実験結果についての総括・講

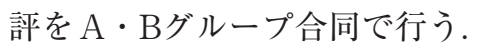

\section{4 接着面積の決定について}

図 7 に現行の接着面積の決定方法を示す. 1 人歩行時 の部材力として, 最大部材力に安全率1.1を乗じ, 2 人歩 行時の部材力には安全率を設けていない。引張試験結果 から得られた最大耐力と接着面積の関倸（近似直線）を 用いて, 1 人歩行時と 2 人歩行時の接着面積を求める. 


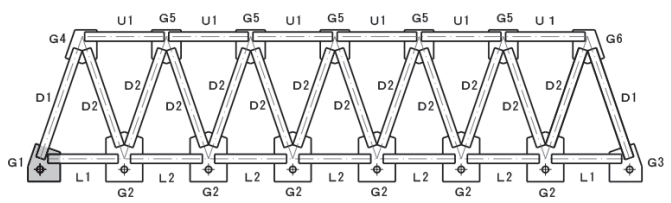

(a) ワーレントラス

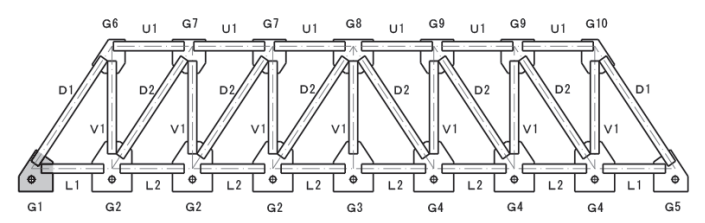

(b) ハウトラス

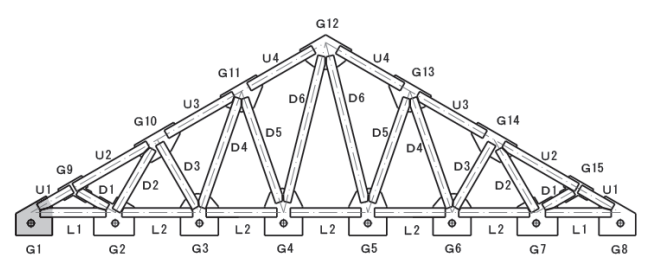

(c) ダブルフィンクトラス

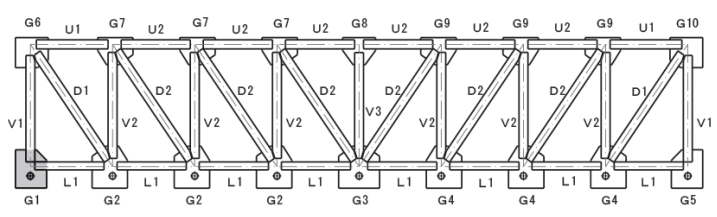

(d) プラットトラス

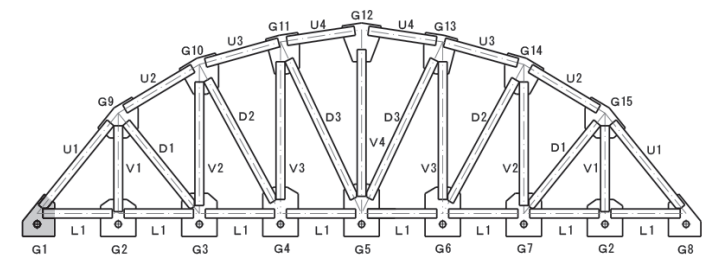

(e) ボウストリングトラス

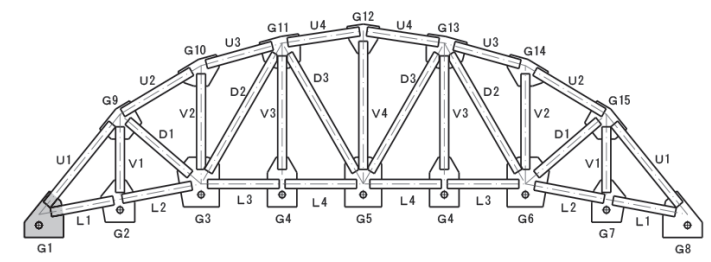

（f）段差ワーレントラス（垂直材あり）

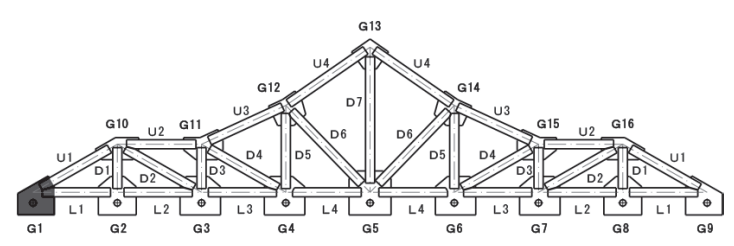

（g）曲弦プラットトラス

図 1 トラス橋の形式

その際, 図 7 に示すように, 両接着面積の間を $4: 1$ の比 率で補間した值を実接着面積としている。接着面積の決 定方法については，2003年度の立ち上げ以降に数回の見 直しを図ってきた，当初は，上記の比率を $2: 1$, その後
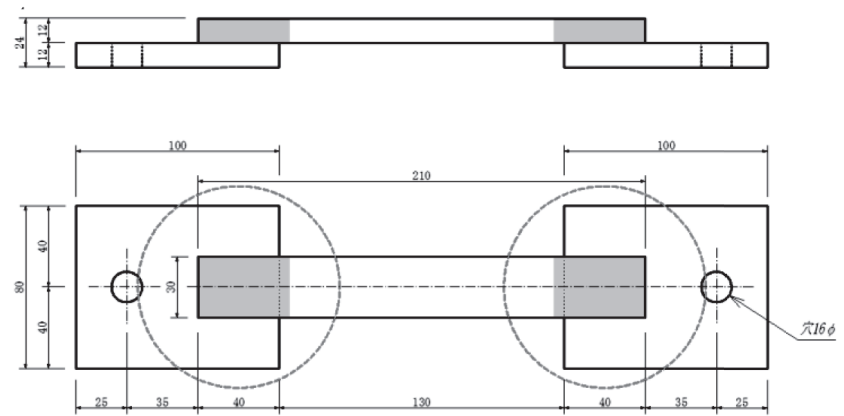

（a）引張試験片の形状・法

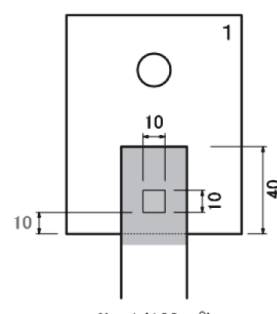

No. $1\left(100 \mathrm{~mm}^{2}\right)$

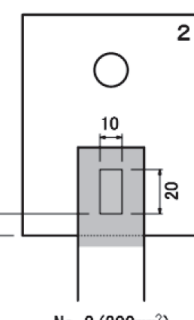

№. $2\left(200 \mathrm{~mm}^{2}\right)$

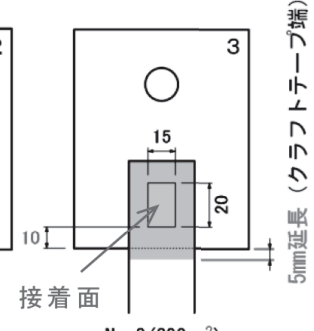

No. $3\left(300 \mathrm{~mm}^{2}\right)$ (b) 引張試験片の種類

図 2 引張試験片
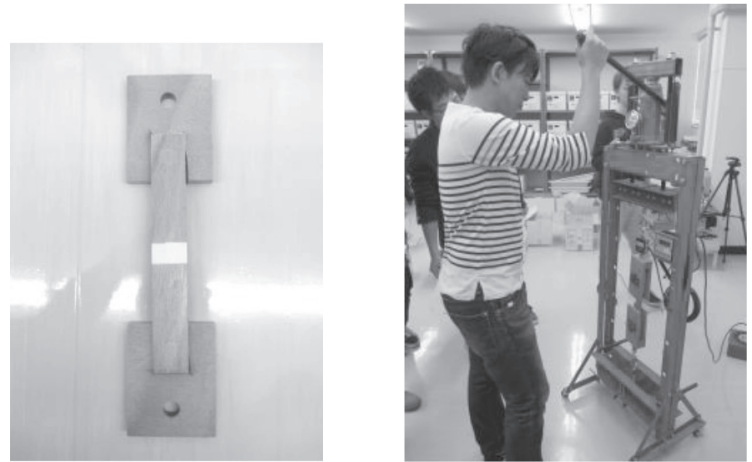

図 3 引張試験片および引張試験状況

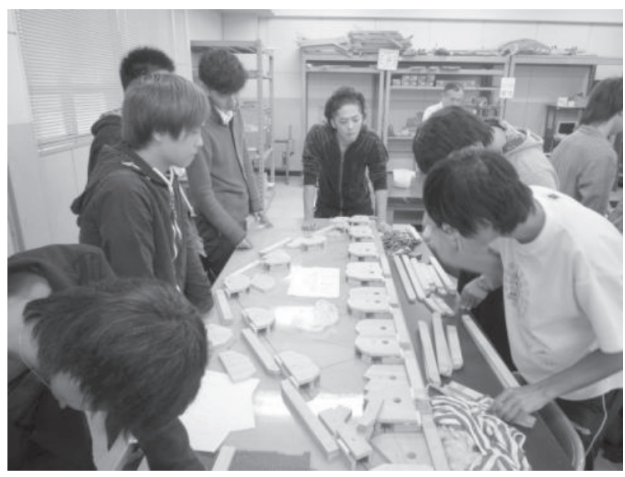

図 4 弦材の切り出し

に $3: 2$ に変更, 2013年度以降は $4: 1$ とさらに安全側へ移 行させてきた。 その理由として, 歩行実験における成功 率の低下が挙げられる. 静定構造物であるトラス橋はひ とつの節点において破壊が生じると, トラス橋全体の崩 壊に繋がるため, 引張試験結果の精度やトラス橋製作の 正確さが大きく影響を及ぼす。トラスの組み立ては数多 くの部材をひとつの班 $7 \sim 8$ 名が協働しての作業になる 


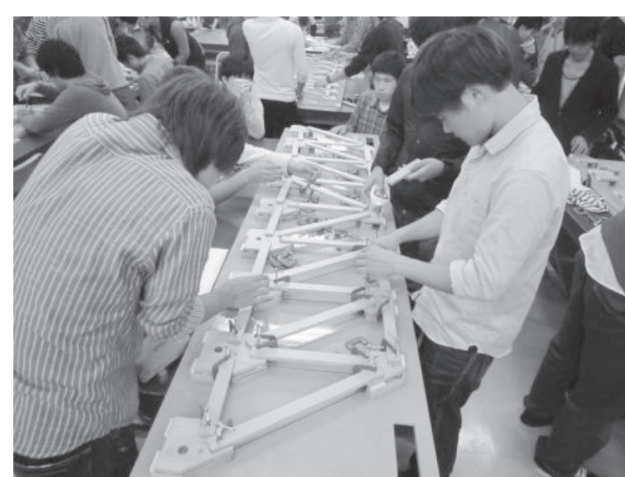

図 5 トラスの組み立て

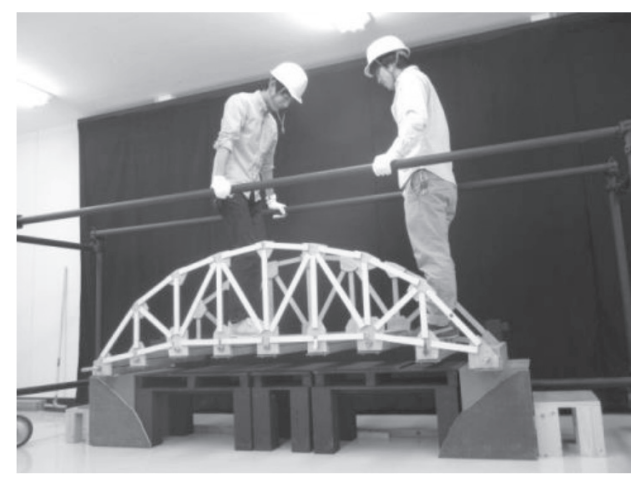

図 6 歩行実験

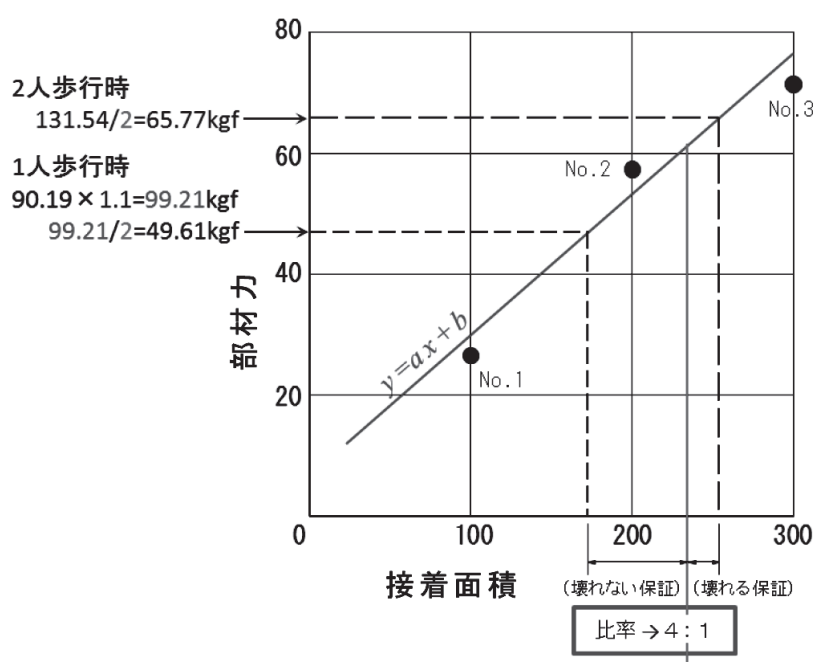

実接着面積 $\left(234 \mathrm{~mm}^{2}\right)$

図 7 接着面積の決定方法

ため, 全員がすべての部材を均一に接着していく必要が ある。 それゆえ, 均一に接着されていないと歩行実験で はそれまでのグループワークの成果が一瞬にして舞結す ることになる，学生のモチベーションや満足感, 歩行実 験時の感動や盛り上がりといったことも考慮しての経緯 が接着面積の決定方法の変更にある.

後述するが，表 2 に示すように，2013年度以降の 1 人 歩行時の成功率は, $67 \sim 92 \%$ 範囲で推移している。一 方, 2 人歩行時に対する接着面積の余裕度が大きくない ため, 2 人歩行時の成功率は $36 \sim 75 \%$ と年度により変動 している. 失敗した班のトラス橋を観察すると, 特に弦
表 2 総合評価点と成功率

\begin{tabular}{|c|c|c|c|c|c|c|}
\hline \multicolumn{2}{|c|}{ 年 度 } & 2017 & 2016 & 2015 & 2014 & 2013 \\
\hline \multicolumn{2}{|c|}{ 総合評価点 } & 8.1 & 7.6 & 7.5 & 7.9 & 8.5 \\
\hline \multirow{2}{*}{ 成功率 } & 1 人歩行 & $11 / 14$ & $8 / 12$ & $10 / 12$ & $11 / 12$ & $8 / 12$ \\
\cline { 2 - 7 } & 2 人歩行 & $3 / 11$ & $4 / 8$ & $5 / 10$ & $4 / 11$ & $6 / 8$ \\
\hline
\end{tabular}

材の接着部において指示内容から逸脱した状況（作業の 粗さ，製作精度の低さなど）が見られることもある。今 後の課題として, 学生への注意喚起や取り組み意欲の低 い学生への対応も検討していく必要がある.

\section{5 成績評価}

本科目に扔ける成績評価は, 各回に扔いて協働して作 業を進めるチームワーク力, トラス橋の製作精度, 歩行 実験の成果 (成功・失敗), レポート, 出席状況を基に行 っている. また, レポート提出時には, 各班における各 人の貢献度を自己申告させ, 成績評価に反映させている.

\section{3. アンケート結果}

本科目では, 本学共通の授業アンケートに加え, 独自 アンケート調查も実施している。 まず, 本学共通の授業 アンケートに扔ける本科目の総合評価点（10点満点, 7 点を“ふつう”）と歩行実験の成功率を表 2 に示す。概ね 8.0 前後の評価点となっており, 成功率の高低が授業アン ケートの評価点に影響しているとは言えない.

次に，本科目で独自に実施しているアンケート調査の 結果について, 本科目を導入した当初の 2003 年度および 2004年度と，ここ 5 年間を比較しながら，本科目の教育 効果を検証する.

図 8 は, トラス橋の歩行実験についての感想である. 一貫して $90 \%$ 程度が「大変楽しかった」あるいは「楽し かった」と回答しており, 本科目の導入当初との差異は 見られない.ただし，「大変楽しかった」の回答率と表 2 に示した 2 人歩行時の成功率は連関している傾向にあ る.

図 9 は, グループ活動に意義を感じたかどうか, 図10 は, リーダーシップは重要なことだと思ったかどうかに ついての回答である.これらの項目は, 本科目の学習教育 目的・目標とするところであり, 本科目を通して, 多く の受講生がグループ活動の意義やリーダーシップの重要 性を感じ取っていることが分かる. 本学科では, 2013年 度からアクティブラーニング科目として，2 年生に「総 合演習 $1 」, \quad 3$ 年生に「総合演習 $2 」$ を新規開講してお り, 2 年生以降の授業においてリーダーシップを実践し ているかどうかの検証も今後検討していく必要がある.

最後に，2013年度からアンケートに追加した項目とし て, 構造力学を学ぶ意義を実感したかどうかについての 回答を図11に示す.本科目は 1 年生の前期に学習した「構 造力学 I」の影響線を援用した実践であることから, $95 \%$ 以上の受講生が構造力学を学ぶ意義を実感できていると 言える. また, 受講生は「基礎ゼミ $2 」$ と並行して,「構 造力学 II」を受講している. 2013年度に大幅なカリキュ ラム改定がなされたことから，それ以降の 5 年間におけ 


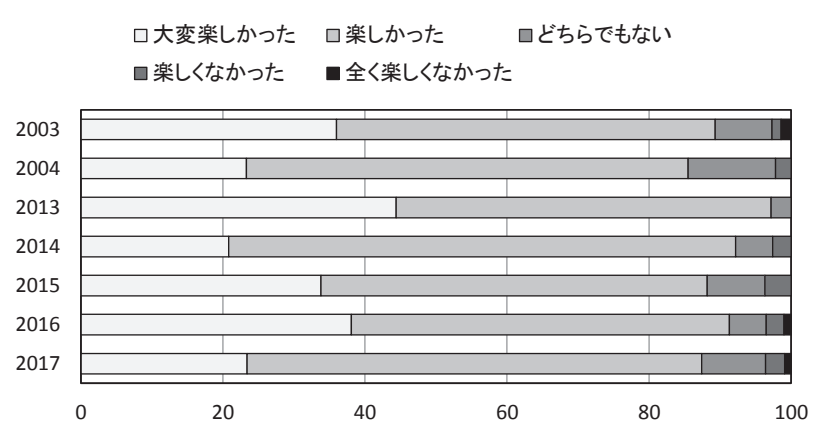

図 8 トラス橋の歩行実験についての感想

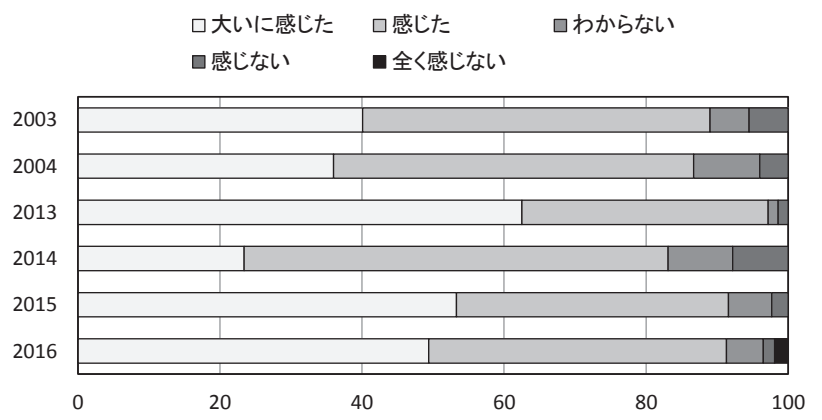

図 9 グループ活動に意義を感じたか

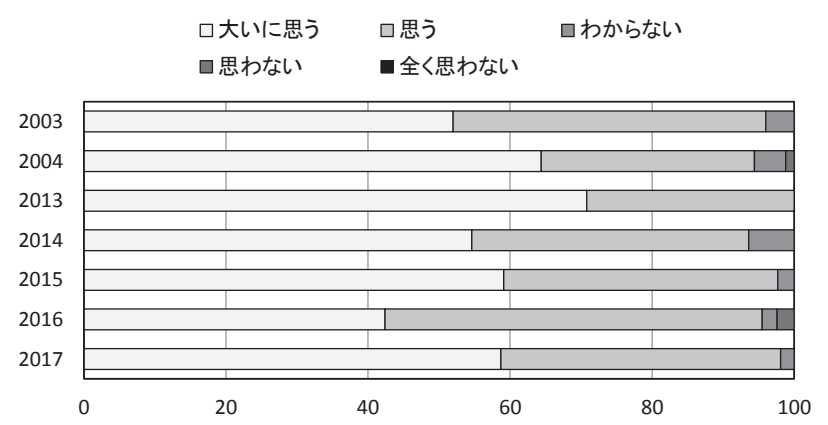

図10 リーダーシップは重要なことだと思ったか

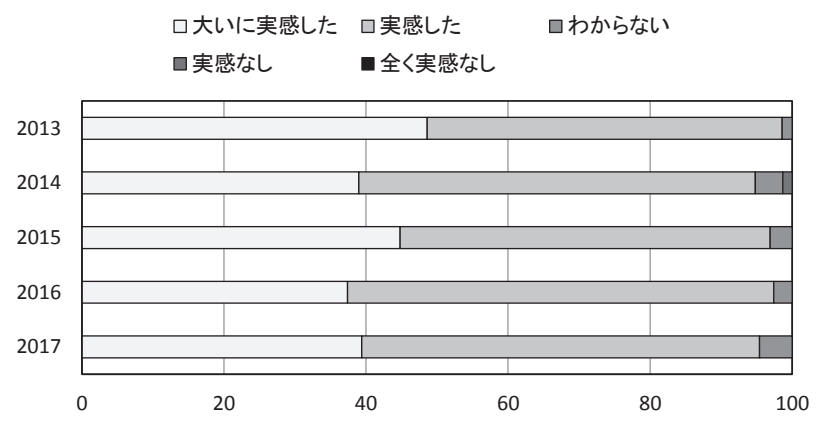

図11構造力学を学ぶ意義を実感したかどうか

る「構造力学 II」の単位修得率の変化をみると, 年度に よる変動はあるものの 2013 年度の $52 \%$ から 2017 年度には $70 \%$ と増加傾向にあり, 勉学への積極的な取り組みの効 果と捉えているが，さらなる検証を行っていく必要があ ると言える。

4.おわりに

本稿では，2003年度から開講した木製トラス橋の製作
および歩行実験を通しての体験型学習について，その内 容とアンケート結果から見られる教育効果について事例 紹介を行った。

アンケート結果から, 受講生は『グループ活動の意義 とリーダーシップの必要性』を体感できており, 学習教 育目的・目標を十分に理解できていると言える。また, 本学科に入学して初めて学習する専門科目である「構造 力学 I」( 1 年生前期) の重要性を理解し,「構造力学 II ( 1 年生後期), さらにそれに続く専門科目に対する学習 の動機づけに一層繋げていけるように特色ある本科目を 今後も実践していく次第である.

\section{参 考 文 献}

1) http://www.canterbury.ac.nz/news/2014/student -bridge-building-competition-.html, 参照日 : 2018$2-27$

2 ） R.M. ガニェ, W.W. ウェイジャー, K.C. ゴラス, J.M. ケラー／岩崎 信, 鈴木克明監訳 : インストラクシ ヨナルデザインの原理, 北大路書房, 2007

3 ）柳下文夫, 谷平 勉, 東山浩士 : 専門科目への動機付 けを目的とした導入教育の実践, 平成16年度工学・ 工業教育研究講演会講演論文集, pp.91-92, 2004

4）柳下文夫, 谷平 勉, 東山浩士 : 創成教育に抢ける指 導方針の検証, 平成 17 年度工学・工業教育研究講演 会講演論文集, pp. $238-239,2005$

5 ）藤野陽三, 阿部雅人：米国ミネソタ州での落橋事故, 土木学会誌, $92-10$, pp. $52-55,2007$

\section{著 者 紹 介}

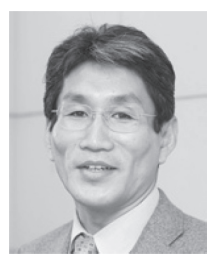

東山 浩士

大阪大学大学院工学研究科博士後期課程修了

学 位 博士 (工学)

現 在 近畿大学理工学部社会環境工学科 教授

専 門 構造工学, 橋梁工学

所属学会 土木学会, 日本コンクリート工学会, アメリカ コンクリート工学会, 日本材料学会, 日本工学 教育協会

連絡先 h-hirosi@civileng.kindai.ac.jp

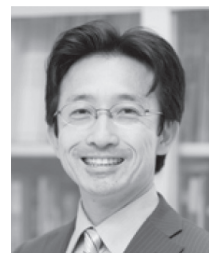

嶋津 治希

広島大学大学院工学研究科博士後期課程修了

学 位 博士 (工学)

現 在 近畿大学理工学部社会環境工学科 准教授

専 門 土木環境工学, 環境化学

所属学会 土木学会, 廃棄物資源循環学会, 日本水環境学 会, 日本環境化学会, アメリカ化学会

連絡先 hshimazu@civileng.kindai.ac.jp

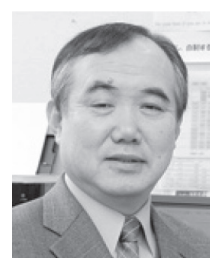

栁下 文夫

日本大学大学院工学研究科博士後期課程修了

学 位 工学博士

現 在 近畿大学理工学部社会環境工学科 教授

専 門 コンクリート工学

所属学会 日本工学教育協会

連絡先 yagisita@civileng.kindai.ac.jp 